\title{
Screening of rice genotypes for salt tolerance by physiological and biochemical characters
}

\author{
Uttam Bhowmik ${ }^{1}$, Mohammad Golam Kibria ${ }^{1}$, Mohammad Saidur Rhaman ${ }^{2}$, Yoshiyuki Murata ${ }^{3} \&$ Md. \\ Anamul Hoque ${ }^{1^{*}}$ \\ ${ }^{1}$ Department of Soil Science, Bangladesh Agricultural University, Mymensingh-2202, Bangladesh \\ ${ }^{2}$ Department of Seed Science and Technology, Bangladesh Agricultural University, Mymensingh-2202, Bangladesh \\ ${ }^{3}$ Graduate School of Environmental and Life Science, Okayama University, Okayama 700-8530, Japan \\ *Email: anamul71@bau.edu.bd
}

\section{ARTICLE HISTORY}

Received: 18 January 2021

Accepted: 08 April 2021

Available online: 01 July 2021

\section{KEYWORDS}

Antioxidant enzymes

Landraces

Physio-biochemical indices

Rice

Salinity

\begin{abstract}
Crop production is unexpectedly hampered by different abiotic stresses. Salinity is one of the leading stresses, which snappishly hampers plant developmental progression. Local rice landraces exhibit noticeable salt tolerance as well as high yield. However, research is scarce about the physiobiochemical responses of local landraces and modern cultivar under saline conditions. Therefore, the present experiment was designed to reveal the physio-biochemical responses of local landraces and modern cultivar under salinity stress. Five landraces (Jotai, Icheburogolghor, Morishal, Chapail, Kumro buro) and two modern cultivars (BR23 and BRRI dhan41) were subjected to $0,20,40,60$ and $80 \mathrm{mM}$ $\mathrm{NaCl}$ treatment. The effects of salt stress on morphological parameters, proline contents, and activities of antioxidant enzymes were assessed. Salt stress reduces the morphological parameters of all tested cultivars. The Morishal and BRRI dhan41 exhibited higher growth of plant and physiological parameters than other cultivars under the highest salinity. The catalase (CAT) and ascorbate peroxidase (APX), exhibited a significant increase whereas peroxidase (POX) activity significantly declined in all the cultivars under salinity stress. Morishal and BRRI dhan41 showed the highest proline content under the maximum saline condition. These results suggest that the high tolerant landrace and modern cultivars were Morishal and BRRI dhan41 respectively. These results also suggest that Morishal and BRRI dhan41 exhibited high tolerance to salinity by enhancing proline content and antioxidant enzyme activities.
\end{abstract}

\section{Introduction}

World population is increasing day by day and it is foreseen that the increasing trend of the population going to be approximately 960 crores by 2050 (1). For the expanding population, it is urgent to enhance crop production by about 44 million MT/year using limited arable lands. Moreover, multiple stresses such as salinity, drought, cold, heat, UV and so on increasing tirelessly. Among the environmental constraints, salinization of soil is the vital stress factor that hinders crop production. Thus, it will be a massive challenge for the future generation to increase crop production by minimizing environmental constraints.

Due to climatic variability, the coastal regions of Bangladesh has been continuously facing different environmental stresses. Among the stresses in the coastal areas, soil salinity appeared as a major threat that causes at least $30-50 \%$ yield loss of different crops and a $15 \%$ decrease in rice yield (2) depending on the level of salinization (3). Approximately, $27 \%$ of the world's land and almost half of the moistened land are affected by salinity $(4,5)$. Nowadays, the soil salinity is appeared as a threat to agricultural systems because it unpleasantly affects plant physiological as well developmental processes (6). Salt stress hampers plant progress and limits yield by interfering photosynthetic rate (7) and accumulation of toxic such as $\mathrm{Na}^{+}$and $\mathrm{Cl}^{-}$ ions (8). Several studies reported soil salinity decreased chlorophyll content (9), increased ROS (10), nutritional disorder (11) and ionic imbalance in plants (12), which finally contributed to significant yield loss (13).

Among the different staple food, rice is the main food for more than half of the world's population (14, 15), and it is a major crop in Bangladesh that covers $80 \%$ of the total cultivable area (16). Rice production is still gaining attention due to the increasing trend of populations. Therefore, the enhancement of rice production is necessary to feed up the increasing trends of the population in Bangladesh. Moreover, a densely-

(c) Bhowmik et al (2021). This is an open-access article distributed under the terms of the Creative Commons Attribution License, which permits unrestricted use, distribution and reproduction in any medium, provided the original author and source are credited (https://creativecommons.org/licenses/by/4.0/). 
populated country like Bangladesh has no scope to annex agricultural lands to cultivate rice to make sure sufficient production. Coastal areas having saline soil in the south-part of Bangladesh could be an auspicious source of arable lands which nearly remain fallow. Besides, climatic fluctuations enhance the extent of salinization of soil in Bangladesh. In this context, the development of salt-tolerant cultivar to maintain optimal crop production can be a way-out to mitigate the salinity crisis in the coastal regions (17).

Several reports indicated multiple plant responses and recommended different approaches to address the hindrances of soil salinization. Possible strategies include growing salt-tolerant rice genotypes (18), supplementation of a compatible solute such as proline (19), organic amendments with $\mathrm{K}$ and $\mathrm{Zn}$ fertilization (20), and modifying antioxidant enzymatic activities (21). As the rice is grown as a major crop in the south-part seaside areas. So the development and/or selection of salt-tolerant rice cultivars might be the best way to enhance rice production in the coastal regions of Bangladesh. In this regard, landrace may be an appropriate contender as it has some distinctive genes that have aided them to thrive in saline areas (17).

Therefore, screening or selecting the best-suited cultivars and exploring their differential responses in saline soil is essential to maintain sustainable rice production in seaside areas of Bangladesh. Salttolerant crop cultivars should be identified based on physio-biochemical responses to salt stress. Therefore, the present work was aimed to explore the physio-biochemical responses of mostly cultivated rice cultivars in coastal regions of Bangladesh for sustainable rice production.

\section{Materials and Methods}

\section{Seed materials}

Five local landraces (Jotai, Icheburogolghor, Morishal, Chapail and Kumro buro) were collected from the saline coastal areas of Batiaghata Upazilla, Khulna. These local landraces were selected due to their distinct phenotype, response to salt stress and yield attributes as well as they are widely cultivated in the coastal regions and two high yielding variety were collected from the Bangladesh Rice Research Institute for physiological and biochemical characterization.

\section{Investigational layout and salt treatments}

The present study was performed in a net-house (with an average temperature of $24{ }^{\circ} \mathrm{C}$ day length 12 $\mathrm{h}$ and $\mathrm{RH} 60 \%$ ) of the Soil Science department, Bangladesh Agricultural University $\left(24^{\circ} 45^{\prime} 8.39^{\prime \prime} \mathrm{N}\right.$ $90^{\circ} 24$ '6.59" E). Homogenously mixed and air-dried soil was collected from the field laboratory of the Soil Science department, BAU. The properties of collected soil were silt loam and exchangeable $\mathrm{Na}$ and $\mathrm{K}$ were $0.383 \mathrm{meq} / 100 \mathrm{gm}$ and $0.082 \mathrm{meq} / 100 \mathrm{gm}$, respectively. Many studies reported that 2 to $12 \mathrm{dS} / \mathrm{m}$ salinity levels negatively affect rice growth and yield $(17,18)$. Moreover, the coastal regions of Bangladesh affect by different ranges of salinity such as very slight (2-4 dS/m), slight (4-8 dS/m) and so on (22). Based on these reports, we selected the $0,20,40,60$ and $80 \mathrm{mM} \mathrm{NaCl}$ doses of salinity and the EC values of soil were $1.00,2.25,5.60,6.58$ and $7.50 \mathrm{dS} / \mathrm{m}$ for 0,20 , 40, 60 and $80 \mathrm{mM} \mathrm{NaCl}$ treatments respectively.

A plastic pot (15 L) was used for the experiment and pot was filled-up with $8 \mathrm{~kg}$ soil and $5 \mathrm{~L}$ water to ensure sufficient space to maintain flooded conditions. Seedlings of rice (30 days old; active tillering stage) were exposed to $0,20,40,60$ and 80 $\mathrm{mM} \mathrm{NaCl}$. For 20, 40 and $60 \mathrm{mM} \mathrm{NaCl}$ treatments, 15.24, 30.47 and $45.71 \mathrm{gm}$ pure $\mathrm{NaCl}$ were dissolved in $1000 \mathrm{~mL}$ water and then added to the pots, respectively. For control, no $\mathrm{NaCl}$ was added to the soils. The experiment was set with 4 replications and designed in a randomized complete block design. For data collection, plants were up-rooted at two-weeks after salt application and morphological parameters like plant height, shoot and root FW and DW and the number of tillers hill ${ }^{-1}$ were recorded.

\section{Measurement of proline contents}

Proline contents were measured following the standard procedure (23). The $0.5 \mathrm{gm}$ of fresh leaves were homogenized in $3 \%$ sulfosalicylic acid and centrifuged at $5000 \mathrm{rpm}$ for $15 \mathrm{~min}$. After centrifugation, $2 \mathrm{ml}$ of supernatant was collected and incubated in acid ninhydrin and glacial acetic acid for $1 \mathrm{hr}$ at $100{ }^{\circ} \mathrm{C}$. After cooling the reaction mixture was extracted with toluene and at $520 \mathrm{~nm}$ the absorbance was recorded.

\section{Measurement of antioxidant enzyme activities \\ CAT activity}

The CAT activity was measured following the standard procedure (21). The $0.5 \mathrm{gm}$ leaf sample was homogenized in a reaction mixture $(50 \mathrm{mM}$ Tris- $\mathrm{HCl}$ buffer, $0.25 \mathrm{mM}$ EDTA, and $20 \mathrm{mM} \mathrm{H}_{2} \mathrm{O}_{2}$ ). Then, the homogenate was centrifuged and the supernatant was collected for measurement of CAT activity.

\section{APX activity}

The APX activity was determined following the standard procedure (24). The $0.5 \mathrm{gm}$ leaf sample was homogenized in a reaction mixture $\left(50 \mathrm{mM} \mathrm{KH}_{2} \mathrm{PO}_{4}\right.$ buffer, $0.1 \mathrm{mM}$ EDTA, $0.1 \mathrm{mM} \mathrm{H}_{2} \mathrm{O}_{2}$ and $0.5 \mathrm{mM}$ AsA). Then, the homogenate was centrifuged and the supernatant was collected for measurement of APX activity.

\section{POX activity}

The POX activity was measured following the standard procedure (24). The $0.5 \mathrm{gm}$ leaf sample was homogenized in a reaction mixture $\left(50 \mathrm{mM} \mathrm{KH}_{2} \mathrm{PO}_{4}\right.$ buffer (pH 7.0), $0.1 \mathrm{mM}$ EDTA, $0.1 \mathrm{mM} \mathrm{H}_{2} \mathrm{O}_{2}$ and 10 $\mathrm{mM}$ guaiacol). Then, the homogenate was centrifuged and the supernatant was collected for measurement of POX activity.

\section{Data analysis}

The collected data were analyzed statistically using “Duncan's Multiple Range Test” to classify significant (5\% level of probability) differences among the treatments. Data were analyzed using GenStat $18^{\text {th }}$ edition for Windows statistical software. 


\section{Results}

\section{Growth parameters (root and shoot)}

The presented results showed that salinity stress decreases the growth of root and shoot of the rice cultivars (Table 1 and $2, \mathrm{P} \leq 0.05$ ). At the highest salt stress ( $80 \mathrm{mM} \mathrm{NaCl}$ ), Morishal exhibited the lowest reduction in fresh weight (FW) (9\%) and dry (43\%) weight (DW) of shoot compared to control. Similar to Morishal, Jotai and Kumro buro also exhibited higher FW, 27.2 and 26.5 and DW, 2.4 and $2.5 \mathrm{~g} / \mathrm{pot}$ respectively, of the shoot at the highest salt stress compared to control (Table 1). The reduction in root FW of Kumro buro was $50 \%$ and in Morishal 16\%, which was the highest and lowest reduction, respectively. However, at $80 \mathrm{mM} \mathrm{NaCl}$, Morishal decreases in root DW by $54 \%$ whereas other cultivars exhibited at least $60 \%$ decrease in root dry weight (Table 2). condition. Under highest stress condition, Icheburogolghor and BRRI dhan41 exhibited 92\% and $54 \%$, respectively, reduction in proline content compared with control. At a high saline level, the maximum proline content was observed in BRRI dhan41 (1.34 mM) and the minimum proline content was in Icheburogolghor $(0.22 \mathrm{mM})$. With increasing salt concentration, intercellular proline content drastically decreased in all the rice cultivars except Morishal and BRRI dhan41.

\section{Antioxidant enzymes, CAT, POX and APX activities}

Activities of antioxidant enzymes were notably influenced by salt stress (Fig. 2). The actions of CAT and APX in all cultivars enhanced with the rising salt concentration (Fig. 2A and 2C). The landraces, Jotai, Morishal and Kumro buro showed significantly higher CAT activity $0.117,0.09,0.09 \mathrm{mmol} / \mathrm{min} / \mathrm{gm} \mathrm{FW}$

Table 1. Shoot fresh and dry weight of seven rice cultivars in response to different levels of soil salinity (0, $20,40,60$ and $80 \mathrm{mM}$ NaCl). Values are means of four replicates and means with the different letters in a column are significantly different $(P \leq 0.05)$.

\begin{tabular}{|c|c|c|c|c|c|c|c|}
\hline \multirow{2}{*}{ Treatments } & \multicolumn{7}{|c|}{ Shoot fresh weight (g/pot) } \\
\hline & Jotai & Icheburogolghor & Morishal & Chapail & Kumro buro & BR 23 & BRRI dhan 41 \\
\hline $0 \mathrm{mM} \mathrm{NaCl}$ & $31.54 \mathrm{a}$ & $29.59 \mathrm{a}$ & $28.50 \mathrm{a}$ & $31.70 \mathrm{a}$ & $30.70 \mathrm{a}$ & $28.70 \mathrm{a}$ & $28.59 \mathrm{a}$ \\
\hline $20 \mathrm{mM} \mathrm{NaCl}$ & $29.54 \mathrm{~b}$ & $27.27 \mathrm{ab}$ & $26.39 \mathrm{~b}$ & $31.30 \mathrm{a}$ & $30.02 \mathrm{ab}$ & $28.29 \mathrm{ab}$ & $28.30 \mathrm{a}$ \\
\hline $40 \mathrm{mM} \mathrm{NaCl}$ & $28.60 \mathrm{bc}$ & $25.84 \mathrm{bc}$ & $26.01 \mathrm{~b}$ & $28.70 \mathrm{~b}$ & $29.29 \mathrm{ab}$ & $26.50 \mathrm{~b}$ & $28.18 \mathrm{a}$ \\
\hline $60 \mathrm{mM} \mathrm{NaCl}$ & $28.53 \mathrm{bc}$ & $25.09 \mathrm{bc}$ & $25.96 \mathrm{~b}$ & $26.29 \mathrm{c}$ & $28.10 \mathrm{bc}$ & $23.20 \mathrm{c}$ & $25.29 \mathrm{~b}$ \\
\hline $80 \mathrm{mM} \mathrm{NaCl}$ & $27.20 \mathrm{c}$ & $23.29 \mathrm{c}$ & $25.98 \mathrm{~b}$ & $23.50 \mathrm{~d}$ & $26.50 \mathrm{c}$ & $18.70 \mathrm{~d}$ & $21.20 \mathrm{c}$ \\
\hline SE ( \pm$)$ & 0.599 & 0.771 & 0.502 & 0.513 & 0.690 & 0.550 & 0.547 \\
\hline \multirow{2}{*}{ Treatments } & \multicolumn{7}{|c|}{ Shoot dry weight (g/pot) } \\
\hline & Jotai & Icheburogolghor & Morishal & Chapail & Kumro buro & BR 23 & BRRI dhan 41 \\
\hline $0 \mathrm{mM} \mathrm{NaCl}$ & $4.100 \mathrm{a}$ & $4.420 \mathrm{a}$ & $3.920 \mathrm{a}$ & $4.250 \mathrm{a}$ & $4.880 \mathrm{a}$ & $3.800 \mathrm{a}$ & $4.950 \mathrm{a}$ \\
\hline $20 \mathrm{mM} \mathrm{NaCl}$ & $3.800 \mathrm{a}$ & $4.100 \mathrm{ab}$ & $3.450 \mathrm{ab}$ & $3.290 \mathrm{~b}$ & $3.720 \mathrm{~b}$ & $3.290 \mathrm{~b}$ & $3.290 \mathrm{~b}$ \\
\hline $40 \mathrm{mM} \mathrm{NaCl}$ & $3.290 \mathrm{~b}$ & $3.820 \mathrm{~b}$ & $3.150 \mathrm{bc}$ & $3.150 \mathrm{bc}$ & $3.450 \mathrm{~b}$ & $2.920 \mathrm{c}$ & $3.150 \mathrm{bc}$ \\
\hline $60 \mathrm{mM} \mathrm{NaCl}$ & $2.790 \mathrm{c}$ & $3.290 \mathrm{c}$ & $2.900 \mathrm{c}$ & $2.900 \mathrm{c}$ & $2.910 \mathrm{c}$ & $2.710 \mathrm{c}$ & $2.900 \mathrm{c}$ \\
\hline 80mM NaCl & $2.42 \mathrm{c}$ & $2.910 \mathrm{c}$ & $2.250 \mathrm{~d}$ & $2.420 \mathrm{~d}$ & $2.520 \mathrm{c}$ & $2.210 \mathrm{~d}$ & $2.420 \mathrm{~d}$ \\
\hline SE ( \pm$)$ & 0.138 & 0.138 & 0.154 & 0.105 & 0.095 & 0.105 & 0.095 \\
\hline
\end{tabular}

\section{Plant height and number of tillers hill ${ }^{1}$}

Similar to other growth characters, plant height and the number of tillers hill-1 ${ }^{-1}$ decrease under salinity stress (Table 3, P $\leq 0.05$ ). Jotai and Icheburogolghor were exhibited the tallest plant $(50.44 \mathrm{~cm})$ and the shortest plants were in BR23 $(38.85 \mathrm{~cm})$ under the highest salinity. Besides, the maximum number of tillers per hill- $^{-1} 8$ was observed in BR23 and the minimum number of tillers per hill-1 3 were in Icheburogolghor under the highest salinity level.

\section{Proline content}

Tested rice cultivars showed significant differences in proline contents in response to salinity levels (Fig. 1). Among the rice cultivars, Kumro buro showed the highest intercellular proline content $(3.0 \mathrm{mM})$ under non-stress condition whereas proline content drastically decreased when exposed to different levels of salt stresses. At $80 \mathrm{mM}$ salt stress, Kumro buro exhibited $86 \%$ reduction of proline content compared to the control. Icheburogolghor and BRRI dhan41 genotypes also showed higher levels of intracellular proline 2.8 and $2.9 \mathrm{mM}$, respectively at the non-stress respectively at the maximum salinity level $(80 \mathrm{mM}$ $\mathrm{NaCl}$ ) whereas BRRI dhan 41 exhibited the highest APX activity $57.14 \mu \mathrm{m} / \mathrm{min} / \mathrm{gm} \mathrm{FW}$ at $80 \mathrm{mM} \mathrm{NaCl}$ compared to other rice cultivars. The actions of POX significantly reduced in all rice cultivars except Chapail with increasing salinity (Fig. 2B). Similar to APX, the POX was also highest in BRRI dhan 41 at the maximum salinity level $(80 \mathrm{mM} \mathrm{NaCl})$.

\section{Discussion}

Many studies showed that salt stress decreased the morphological parameters of different crops (17, 25, 26). In this study, the shoot (Table 1 ) and the root (Table 2) growth, as well as the plant height and number of tillers hill ${ }^{-1}$ (Table 3), were reduced in all cultivars under salinization. Similar results were reported in hybrid rice and maize under salinity stress $(27,28)$. A greater decrease in shoot and root biomass accumulation was observed in Kumro buro than Morishal and BRRI dhan 41 at $80 \mathrm{mM} \mathrm{NaCl}$ level. This result may indicate a better salt resistance in BBRI dhan41 and Morishal 
Table 2. Root fresh and dry weight of seven rice cultivars in response to different levels of soil salinity (0, 20, 40, 60 and $80 \mathrm{mM} \mathrm{NaCl}$ ). Values are means of four replicates and means with the different letters in a column are significantly different $(P \leq 0.05)$.

\begin{tabular}{|c|c|c|c|c|c|c|c|}
\hline \multirow{2}{*}{ Treatments } & \multicolumn{7}{|c|}{ Root fresh weight (g/pot) } \\
\hline & Jotai & Icheburogolghor & Morishal & Chapail & Kumro buro & BR 23 & BRRI dhan 41 \\
\hline $0 \mathrm{mM} \mathrm{NaCl}$ & $7.800 \mathrm{a}$ & $7.790 \mathrm{a}$ & $7.350 \mathrm{a}$ & $8.500 \mathrm{a}$ & $8.880 \mathrm{a}$ & $8.900 \mathrm{a}$ & $7.200 \mathrm{a}$ \\
\hline $20 \mathrm{mM} \mathrm{NaCl}$ & $7.100 \mathrm{~b}$ & $7.250 \mathrm{~b}$ & $7.120 \mathrm{ab}$ & $8.350 \mathrm{a}$ & $8.160 \mathrm{ab}$ & $7.250 \mathrm{~b}$ & $7.000 \mathrm{a}$ \\
\hline $40 \mathrm{mM} \mathrm{NaCl}$ & $6.100 \mathrm{c}$ & $6.920 \mathrm{bc}$ & $6.830 \mathrm{ab}$ & $8.100 \mathrm{a}$ & $7.290 \mathrm{~b}$ & $7.050 \mathrm{~b}$ & $6.920 \mathrm{a}$ \\
\hline $60 \mathrm{mM} \mathrm{NaCl}$ & $5.350 \mathrm{~d}$ & $6.790 \mathrm{c}$ & $6.560 \mathrm{bc}$ & $7.200 \mathrm{~b}$ & $5.320 \mathrm{c}$ & $6.820 \mathrm{~b}$ & $6.820 \mathrm{a}$ \\
\hline $80 \mathrm{mM} \mathrm{NaCl}$ & $4.980 \mathrm{~d}$ & $6.300 \mathrm{~d}$ & $6.150 \mathrm{c}$ & $6.900 \mathrm{~b}$ & $4.520 \mathrm{c}$ & $6.850 \mathrm{~b}$ & $5.950 \mathrm{~b}$ \\
\hline SE ( \pm$)$ & 0.115 & 0.124 & 0.194 & 0.171 & 0.321 & 0.303 & 0.129 \\
\hline \multirow{2}{*}{ Treatments } & \multicolumn{7}{|c|}{ Root dry weight (g/pot) } \\
\hline & Jotai & Icheburogolghor & Morishal & Chapail & Kumroburo & BR 23 & BRRI dhan 41 \\
\hline $0 \mathrm{mM} \mathrm{NaCl}$ & $1.400 \mathrm{a}$ & $1.220 \mathrm{a}$ & $1.310 \mathrm{a}$ & $1.210 \mathrm{a}$ & $1.330 \mathrm{a}$ & $1.150 \mathrm{a}$ & $1.520 \mathrm{a}$ \\
\hline $20 \mathrm{mM} \mathrm{NaCl}$ & $0.900 \mathrm{~b}$ & $0.800 \mathrm{~b}$ & $1.150 \mathrm{a}$ & $0.920 \mathrm{~b}$ & $0.690 \mathrm{~b}$ & $0.920 \mathrm{~b}$ & $1.090 \mathrm{~b}$ \\
\hline $40 \mathrm{mM} \mathrm{NaCl}$ & $0.790 \mathrm{bc}$ & $0.780 \mathrm{~b}$ & $0.850 \mathrm{~b}$ & $0.870 \mathrm{~b}$ & $0.670 \mathrm{~b}$ & $0.780 \mathrm{~b}$ & $0.910 \mathrm{c}$ \\
\hline $60 \mathrm{mM} \mathrm{NaCl}$ & $0.720 \mathrm{c}$ & $0.590 \mathrm{c}$ & $0.720 \mathrm{bc}$ & $0.790 \mathrm{~b}$ & $0.540 \mathrm{c}$ & $0.620 \mathrm{c}$ & $0.820 \mathrm{c}$ \\
\hline $80 \mathrm{mM} \mathrm{NaCl}$ & $0.500 \mathrm{~d}$ & $0.520 \mathrm{c}$ & $0.590 \mathrm{c}$ & $0.500 \mathrm{c}$ & $0.410 \mathrm{~d}$ & $0.420 \mathrm{~d}$ & $0.700 \mathrm{~d}$ \\
\hline SE ( \pm$)$ & 0.044 & 0.033 & 0.057 & 0.038 & 0.028 & 0.048 & 0.035 \\
\hline
\end{tabular}

Table 3. Plant height and number of tillers per hill of seven rice cultivars in response to different levels of soil salinity ( 0 , 20 , 40,60 and $80 \mathrm{mM} \mathrm{NaCl})$. Values are means of four replicates and means with the different letters in a column are significantly different $(P \leq 0.05)$.

\begin{tabular}{|c|c|c|c|c|c|c|c|}
\hline \multirow{2}{*}{ Treatments } & \multicolumn{7}{|c|}{ Plant height $(\mathrm{cm})$} \\
\hline & Jotai & Icheburogolghor & Morishal & Chapail & Kumro buro & BR 23 & BRRI dhan 41 \\
\hline $0 \mathrm{mM} \mathrm{NaCl}$ & $60.50 \mathrm{a}$ & $59.83 \mathrm{a}$ & $52.48 \mathrm{a}$ & $62.06 \mathrm{a}$ & $56.22 \mathrm{a}$ & $48.66 \mathrm{a}$ & $58.47 \mathrm{a}$ \\
\hline $20 \mathrm{mM} \mathrm{NaCl}$ & $57.60 \mathrm{a}$ & $57.60 \mathrm{ab}$ & $46.55 \mathrm{~b}$ & $52.33 \mathrm{~b}$ & $48.40 \mathrm{~b}$ & $47.48 \mathrm{a}$ & $56.22 \mathrm{a}$ \\
\hline $40 \mathrm{mM} \mathrm{NaCl}$ & $56.42 \mathrm{ab}$ & $56.42 \mathrm{ab}$ & $42.33 \mathrm{c}$ & $50.89 \mathrm{~b}$ & $47.61 \mathrm{bc}$ & $41.72 \mathrm{~b}$ & $56.34 \mathrm{a}$ \\
\hline $60 \mathrm{mM} \mathrm{NaCl}$ & $54.33 \mathrm{ab}$ & $54.33 \mathrm{bc}$ & $42.48 \mathrm{c}$ & $48.33 \mathrm{~b}$ & $46.58 \mathrm{bc}$ & $41.66 \mathrm{~b}$ & $54.75 \mathrm{ab}$ \\
\hline $80 \mathrm{mM} \mathrm{NaCl}$ & $50.44 \mathrm{~b}$ & $50.44 \mathrm{c}$ & $41.63 \mathrm{c}$ & $47.14 \mathrm{~b}$ & $42.47 \mathrm{c}$ & $38.85 \mathrm{~b}$ & $50.33 \mathrm{~b}$ \\
\hline $\mathrm{SE( \pm )}$ & 1.78 & 1.28 & 1.11 & 1.82 & 1.56 & 1.37 & 1.41 \\
\hline \multirow{2}{*}{ Treatments } & \multicolumn{7}{|c|}{ Number of tillers per hill } \\
\hline & Jotai & Icheburogolghor & Morishal & Chapail & Kumro buro & BR 23 & BRRI dhan 41 \\
\hline $0 \mathrm{mM} \mathrm{NaCl}$ & $8.00 \mathrm{a}$ & $8.00 \mathrm{a}$ & $8.00 \mathrm{a}$ & $7.00 \mathrm{a}$ & $7.00 \mathrm{a}$ & $8.00 \mathrm{a}$ & $7.00 \mathrm{a}$ \\
\hline $20 \mathrm{mM} \mathrm{NaCl}$ & $7.00 \mathrm{ab}$ & $6.00 \mathrm{~b}$ & $8.00 \mathrm{a}$ & $7.00 \mathrm{a}$ & $6.00 \mathrm{~b}$ & $8.00 \mathrm{a}$ & $7.00 \mathrm{a}$ \\
\hline $40 \mathrm{mM} \mathrm{NaCl}$ & $6.00 \mathrm{bc}$ & $5.00 \mathrm{bc}$ & $7.00 \mathrm{~b}$ & $5.66 \mathrm{~b}$ & $5.00 \mathrm{c}$ & $8.00 \mathrm{a}$ & $6.00 \mathrm{~b}$ \\
\hline $60 \mathrm{mM} \mathrm{NaCl}$ & $5.00 \mathrm{~cd}$ & $4.00 \mathrm{~cd}$ & $6.00 \mathrm{c}$ & $5.00 \mathrm{~b}$ & $6.00 \mathrm{~b}$ & $7.00 \mathrm{~b}$ & $5.00 \mathrm{c}$ \\
\hline $80 \mathrm{mM} \mathrm{NaCl}$ & $4.00 \mathrm{~d}$ & $3.33 \mathrm{~d}$ & $5.00 \mathrm{~d}$ & $5.00 \mathrm{~b}$ & $4.00 \mathrm{~d}$ & $6.00 \mathrm{c}$ & $4.00 \mathrm{~d}$ \\
\hline $\mathrm{SE}( \pm)$ & 0.415 & 0.363 & 0.256 & 0.347 & 0.158 & 0.211 & 0.194 \\
\hline
\end{tabular}

compared to Kumro buro, which might be attributed to being more tolerant to salt stress.

Intracellular proline contents gradually decreased in cultivars with the rising of salinization (Fig. 1). Among the cultivars, BRRI dhan41 contains a high level of proline at $80 \mathrm{mM} \mathrm{NaCl}$. High proline contents in BRRI dhan41 indicate that cultivar BRRI dhan41 may be more salinity tolerant to other cultivars. In the case of soybean similar result was found and that result showed proline content was enhanced in soybean with the rising of salinization (29). Salt-sensitive rice cultivar KDML105 and Thai jasmine rice showed an increasing pattern of proline content under salt stress $(30,31)$.

Antioxidant enzymes are the key regulator for the mitigation of abiotic stresses in crop production $(19,32)$. Antioxidant enzymatic activities contributed to increasing salt-tolerant of rice cultivars exposed to the different levels of salt stress (Fig. 2). Our results showed the actions of CAT and APX significantly enhanced under salt stress (Fig. 2A and 2C), whereas the actions of POX reduced under salt stress (Fig. 2B). Similarly many researchers reported that the actions of APX synchronized with the actions of CAT and POX in rice and cotton during salinity stress $(33,34)$. In this present study, BRRI dhan 41 and Morishal exhibited higher CAT, POX and APX activities compared to other cultivars under salt stress. It is important to mention that BRRI dhan41 and Morishal also exhibited significantly higher proline contents at the highest salt level. These results indicate and suggest that the higher antioxidant enzyme activities coupled with higher intercellular proline content might play a key role in salinity tolerance to these cultivars.

It has been reported that genotypes of rice varied in capacity to withstand the salinization when grown in a range of soil salinity (18). In this study, Morishal exhibited the lowest percent decrease in dry biomass accumulation at the highest salt stress compared to control. It is essential to mention that the rice cultivars used in this study demonstrated differential responses to withstand soil salinity. The findings were compatible with the study (18), which revealed rice cultivars fluctuate significantly in their capacity to withstand soil salinity. Variation in the ability to withstand salinity investigated in this work may have a potential for genetic selection for higher salt tolerance as well as may assist in determining the best-suited rice cultivars for coastal areas of Bangladesh.

\section{Conclusion}

It is concluded that salt stress negatively affected rice cultivars with a significant decrease in their physiological and biochemical aspects. Among the tested rice cultivars, Morishal and BRRI dhan41 exhibited high tolerance to salinity by enhancing 


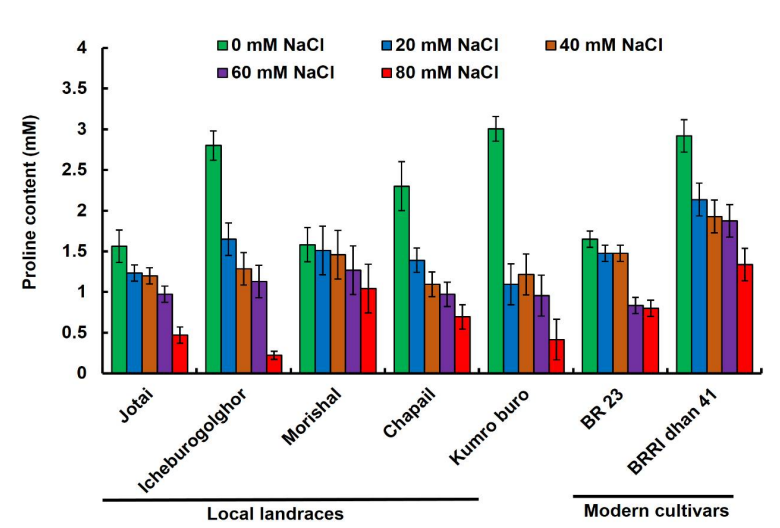

Fig. 1. Proline content of landraces and modern cultivars in response to different levels of soil salinity $(0,20,40,60$ and 80 $\mathrm{mM} \mathrm{NaCl}$ ). Values are means $\pm \mathrm{SE}$ of four replicates.

intracellular proline content and antioxidant enzyme activities. Furthermore, morphological data such as yield and biochemical data chlorophyll content and SOD activity should be performed to more validation of our results.

\section{Acknowledgements}

This study was funded by the Ministry of Education, Government of Bangladesh.

\section{Authors' contributions}

Conceptualization, Methodology and Supervision: MAH; Formal analysis and investigation: UB \& MGK; Writing original draft preparation: UB \& MSR; Writing - review and editing: YM, MAH \& MSR.

\section{Conflict of interests}

The authors declare no conflict of interest.

\section{References}

1. Melorose J, Perroy R, Careas S. World population prospects: The 2015 Revision, Key Findings and Advance Tables. Working Paper No. ESA/P/WP.241, 2015. pp 1-59.

2. Dasgupta S, Hossain MM, Huq M, Wheeler D. Climate change, salinization andhigh-yield rice production in coastal Bangladesh. Agric Res Econ Rev. 2017;47(1):66-89. https://doi.org/10.1017/age.2017.14

3. Alam MZ, Carpenter-Boggs L, Mitra S, Haque MM, Halsey J, Rokonuzzaman M, Saha B, Moniruzzaman M. Effect of salinity intrusion on food crops, livestock and fish species at Kalapara coastal belt in Bangladesh. J Food Qual. Article ID 2045157, 2017;123. https://doi.org/10.1155/2017/2045157

4. Zhu JK. Regulation of ion homeostasis under salt stress. Curr Opin Plant Biol. 2003;6 (5):441-45. https://doi.org/10.1016/s13695266(03)00085-2

5. Machado RM, Serralheiro RP. Soil salinity: effect on vegetable crop growth. Management practices to prevent and mitigate soil salinization. Horticulturae. https://doi.org/10.3390/horticulturae3020030

2017;3(2):30.

6. Shrivastava P, Kumar R. Soil salinity: A serious environmental issue and plant growth promoting bacteria as one of the tools for its alleviation. Saudi J Biol Sci. 2015;22(2): 123-31. https://doi.org/10.1016/j.sjbs.2014.12.001
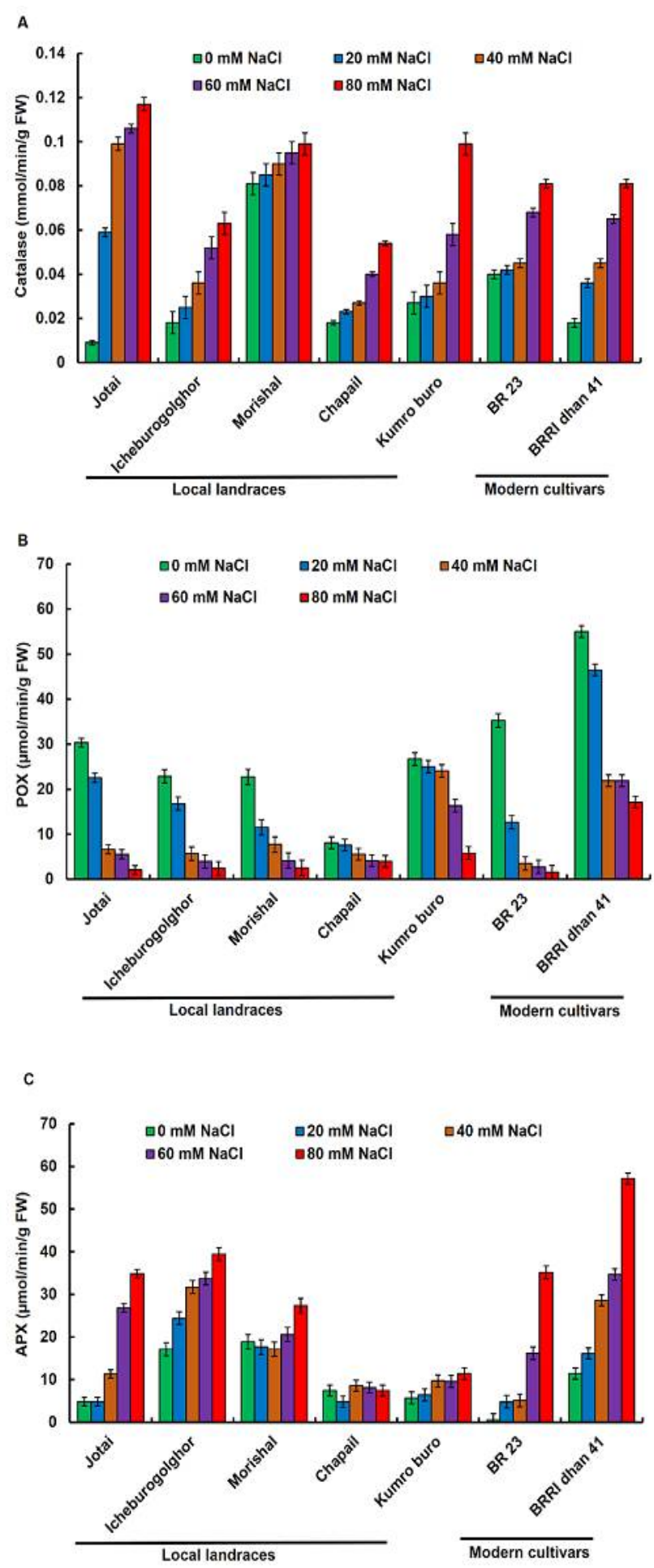

Fig. 2. Antioxidant enzymatic activities (catalase, CAT (A); peroxidase, POX (B); ascorbate peroxidase, APX (C) ) of landraces and modern cultivars in response to different levels of soil salinity $(0,20,40,60$ and $80 \mathrm{mM} \mathrm{NaCl})$. Values are means $\pm \mathrm{SE}$ of four replicates.

7. Yang X, Li Y, Chen H, Huang J, Zhang Y, Qi M, Liu Y, Li T. Photosynthetic response mechanism of soil salinity-induced cross-tolerance to subsequent drought stress in tomato plants. Plants 2020;9(3):363. https://doi.org/10.3390/plants9030363

8. Assaha DVM, Ueda A, Saneoka H, Al-Yahyai R, Yaish MW. The role of $\mathrm{Na}(+)$ and $\mathrm{K}(+)$ transporters in salt stress adaptation in $\begin{array}{lll}\text { glycophytes. } & \text { Front } & \text { Physiol. }\end{array}$ https://doi.org/10.3389/fphys.2017.00509

9. Taïbi K, Taïbi F, Ait Abderrahim L, Ennajah A, Belkhodja M, Mulet JM. Effect of salt stress on growth, chlorophyll content, lipid peroxidation and antioxidant defence systems in Phaseolus 
vulgaris L. S. Afr J Bot. 2016;105:306-12. https://doi.org/10.1016/j.sajb.2016.03.011

10. Yasar F, Ellialtioglu S, Yildiz K. Effect of salt stress on antioxidant defense systems, lipid peroxidation and chlorophyll content in green bean. Russ J Plant Physiol. 2008;55(6):782-86. https://doi.org/ $10.1134 / \mathrm{S} 1021443708060071$

11. Zhang JL, Flowers TJ, Wang SM. Mechanisms of sodium uptake by roots of higher plants. Plant Soil 2010;326(1-2):45-60 https://doi.org/10.1007/s11104-009-0076-0

12. Gupta B, Huang B. Mechanism of salinity tolerance in plants: physiological, biochemical and molecular characterization. Int J Genomics. 2014;701596. https://doi.org/10.1155/2014/701596

13. Kibria MG, Hoque MA. A review on plant responses to soil salinity and amelioration strategies. Op J Soil Sci. 2019;9(11):219-31. https:// doi.org/10.4236/ojss.2019.911013

14. Dawe D. The contribution of rice research to poverty alleviation. In: Studies in Plant Science, vol 7. Elsevier, 2000; pp. 3-12. http://dx.doi.org/10.1142/9789812709523_0003

15. Rhaman MS, Kibria MG, Hossain M, Hoque MA. Effects of organic manure and bio-slurries with chemical fertilizers on growth and yield of rice (cv. BRRI dhan28). Int J Expt Agric. 2016;6(3):36-42.

16. FAO. Crop and Food Supply Assessment Mission to Bangladesh. 2017.

17. Tahjib-Ul-Arif M, Sayed MA, Islam MM, Siddiqui MN, Begum SN, Hossain MA. Screening of rice landraces (Oryza sativa L.) for seedling stage salinity tolerance using morpho-physiological and molecular markers. Acta Physiol Plant. 2018;40(4):70. http://dx.doi.org/10.1007/s11738-018-2645-4

18. Kibria MG, Hossain MA, Murata Y, Hoque MA. Antioxidant defense mechanisms of salinity tolerance in rice genotypes. Rice Sci. 2017;24(3):155-62. https://doi.org/10.1016/j.rsci.2017.05.001

19. Bhusan D, Das DK, Hossain MA, Murata Y, Hoque MA. Improvement of salt tolerance in rice (Oryza sativa L.) by increasing antioxidant defense systems using exogenous application of proline. Aust J Crop Sci. 2016;10(1):50-56

20. Kibria MG, Farhad, Hoque MA. Alleviation of soil salinity in rice by potassium and zinc fertilization. Int J Expt Agric. 2015;5(3):15-21.

21. Islam MM, Hoque MA, Okuma E, Banu MN, Shimoishi Y, Nakamura Y, Murata Y. Exogenous proline and glycinebetaine increase antioxidant enzyme activities and confer tolerance to cadmium stress in cultured tobacco cells. J Plant Physiol. 2009;166 (15):1587-97. https://doi.org/10.1016/j.jplph.2009.04.002

22. Haque SA. Salinity problems and crop production in coastal regions of Bangladesh. Pakistan Journal of Botany. 2006 Dec 1;38(5):1359-65.

23. Bates LS, Waldren RP, Teare ID. Rapid determination of free proline for water-stress studies. Plant Soil. 1973;39(1):205-07. https://doi.org/10.1007/BF00018060

24. Hoque MA, Okuma E, Banu MN, Nakamura Y, Shimoishi Y, Murata Y. Exogenous proline mitigates the detrimental effects of salt stress more than exogenous betaine by increasing antioxidant enzyme $\begin{array}{llll}\text { activities. J Plant Physiol. 2007;164 (5):553-61. } & \end{array}$ https://doi.org/10.1016/j.jplph.2006.03.010

25. Dadkhah AR, Stewart WS, Griffith H. Effects of salinity on yield and root quality of sugar beet (Beta vulgaris L.). J Exp Bot. 2001;52:31.
26. Momayezi MR, Rahman ZZ, Mosa HM, Ismail MR. Effect of chloride and sulfate salinity on nutrient uptake in Iranian rice (Oryza sativa L.) In: 19th World Congress of Soil Science, Brisbane, Australia, 1-6 August 2010.

27. Tuna AL, Kaya C, Dikilitas M, Higgs D. The combined effects of gibberellic acid and salinity on some antioxidant enzyme activities, plant growth parameters and nutritional status in maize plants. Environ Exp Bot. 2008;62(1):1-9. https://doi.org/10.1016/j.envexpbot.2007.06.007

28. Islam MT, Sharma PC, Gautam RK, Singh D, Singh S, Panesar B, Ali S. Salt tolerance in parental lines of rice hybrids through physiological attributes molecular markers. Int J Exp Agric. 2011;2(1):1-7.

29. Weisany W, Sohrabi Y, Heidari G, Siosemardeh A, GhassemiGolezani K. Changes in antioxidant enzymes activity and plant performance by salinity stress and zinc application in soybean (Glycine max L.). Plant Omics 2012;5(2):60-67.

30. Nounjan N, Nghia PT, Theerakulpisut P. Exogenous proline and trehalose promote recovery of rice seedlings from salt-stress and differentially modulate antioxidant enzymes and expression of related genes. J Plant Physiol. 2012;169(6):596-604 https://doi.org/10.1016/j.jplph.2012.01.004

31. Summart J, Thanonkeo P, Panichajakul S, Prathepha P, McManus MT. Effect of salt stress on growth, inorganic ion and proline accumulation in Thai aromatic rice, Khao Dawk Mali 105, callus culture. Afr J Biotechnol. 2010;9(2):145-52.

32. Khatun M, Matsushima D, Rhaman MS, Okuma E, Nakamura T, Nakamura Y, Munemasa S, Murata Y. Exogenous proline enhances antioxidant enzyme activities but does not mitigate growth inhibition by selenate stress in tobacco BY-2 cells. Biosci Biotechnol Biochem. 2020;84(11):2281-92. https://doi.org/10.1080/09168451.2020.1799747

33. Meloni DA, Oliva MA, Martinez CA, Cambraia J. Photosynthesis and activity of superoxide dismutase, peroxidase and glutathione reductase in cotton under salt stress. Environ Exp Bot 2003;49(1):69-76. https://doi.org/10.1016/S0098-8472(02)00058-8

34. Caverzan A, Piasecki C, Chavarria G, Stewart CN, Vargas L. Defenses against ROS in crops and weeds: The effects of interference and herbicides. Int J Mol Sci. 2019;20(5):1086. https://doi.org/ 10.3390/ijms20051086

\section{Additional information}

Peer review information: Plant Science Today thanks Sectional Editor and the other anonymous reviewers for their contribution to the peer review of this work.

Reprints and permissions information is available at https://horizonepublishing.com/journals/index.php/PST/open_access_policy

Publisher's Note: Horizon e-Publishing Group remains neutral with regard to jurisdictional claims in published maps and institutional affiliations.

To cite this article: Bhowmik U, Kibria M G, Rhaman M S, Murata Y, Hoque M A. Screening of rice genotypes for salt tolerance by physiological and biochemical characters. Plant Science Today. 2021;8(3):467-472. https://doi.org/10.14719/pst.2021.8.3.1098

Plant Science Today, published by Horizon e-Publishing Group, is covered by Scopus, Web of Science, BIOSIS Previews, Clarivate Analytics, etc. See https://horizonepublishing.com/journals/index.php/PST/indexing_abstracting 